\title{
X線自由電子レーザーを目指したレーザー航跡場加速研究の現状
}

\author{
細貝 知直 ${ }^{1,2}$, 大塚 崇光 ${ }^{1}$, 兒玉 了祐 ${ }^{1,2,3}$ \\ ${ }^{1}$ 大阪大学 光科学センター ( ₹565-0871 大阪府吹田市山田丘2-1) \\ ${ }^{2}$ 大阪大学大学院 工学研究科 ( ₹ 565-0871 大阪府吹田市山田丘2-1) \\ ${ }^{3}$ 大阪大学レーザーエネルギー学研究センター（５65-0871 大阪府吹田市山田丘2-6)
}

\section{Status of Laser Wakefield Acceleration Research Aiming for X-ray Free Electron Laser}

\author{
Tomonao HOSOKAI ${ }^{1,2}$, Takamitsu OTSUKA ${ }^{1}$, and Ryosuke KODAMA ${ }^{1,2,3}$ \\ ${ }^{1}$ Photon Pioneers Center, 2-1 Yamadaoka, Suita, Osaka 565-0871 \\ ${ }^{2}$ Graduate School of Engineering, Osaka University, 2-1 Yamada-oka, Suita, Osaka 565-0871 \\ ${ }^{3}$ Institute of Laser Engineering, Osaka University, 2-6 Yamada-oka, Suita, Osaka 565-0871
}

(Received January 2, 2017)

\begin{abstract}
We review laser wakefield acceleration (LWFA) research that aims at table-top sized X-ray free-electron laser (XFEL) based on LWFA under the ImPACT program. LWFA is expected to be a novel scheme for accelerating electron beams beyond $\mathrm{GeV}$-class energy with compact devices. In recent studies, the pointing stability of the electron beams from LWFA has been dramatically improved by plasma-microoptics (PMO) that function as a focusing and optical-guiding tool for intense laser pulses. The PMO enables electron beams to be precisely controlled and/or transported by the beam-optics of conventional accelerators. With these techniques a staging LWFA has been demonstrated successfully, and high quality quasi-mono-energetic beams below the $100 \mathrm{MeV}$ range are produced with good repeatability. Sub-GeV electron beams are also produced with the boosters. Finally, we introduce a new facility that includes a laser system designed for the exclusive use of the laser-driven XFEL, which is under construction at the RIKEN-Harima-Campus.
\end{abstract}

Key Words: Staged laser wakefield acceleration, X-ray free electron laser

\section{1. はじめに}

X線自由電子レーザー(X-ray Free Electron Laser: XFEL) はこれまでの短波長放射光光源が達成し得ない高いピー ク輝度, 高い空間コヒーレンス及びフェムト秒オーダー の極短パルス性を特徵とする極短波長光源である．材料 科学ではこの光源の極めて高いピーク輝度と極短パルス 性を活かし，フェムト秒かつオングストロームオーダー の高い時間空間分解能で物質ダイナミクスの直接観測 を，また，超高圧物性物理では集光強度が $10^{20} \mathrm{~W} / \mathrm{cm}^{2}$ を 越える高いパワー密度により極限超高圧下のサイエンス が拓かれている。ささらに生物医学や創薬など様々な基礎 科学分野の超高速過渡現象の解明にも劇的な変革をもた らし, 今後もさらなる応用展開が期待されている ${ }^{1-3)}$

しかしながら，XFELはGeV級の直線加速器と波長数 センチの周期磁場構造を持つ巨大なアンジュレータに よって構成されるため, 理化学研究所播磨キャンパスで 現在稼働中の世界最小XFEL装置SACLA (SPring-8 Angstrom Compact Free Electron LAser)でさえ総延長700 mに も達する $(400 \mathrm{~m}$ の $8 \mathrm{GeV}$ 直線加速器棟, $240 \mathrm{~m}$ の光源棟
(真空封込み型アンジュレータ), $60 \mathrm{~m}$ の実験研究棟よ り成る)。装置規模が巨大であるため建設と運用には国 家プロジェクト規模の莫大な資金を必要とし，既に欧州 とアジアで建設が始まっているものの, 現在稼働してい るXFELは米国のLCLS (SLAC Linac Coherent Light Source) と日本のSACLAの二つの施設のみである. フォトンコ ストは極めて高価となり, 従って限られた研究課題にの み使用が許される。もしXFELが大学や企業の研究室で 運用可能なサイズにまで小型化すれば，研究分野の裾野 は大きく広がり基礎科学から応用までの幅広い研究展開 や新しい極限科学の創出が期待されるのみならず，産業 への貢献も計り知れない.

XFELでは

$$
\lambda_{\mathrm{FEL}}=\frac{\lambda_{\mathrm{u}}}{2 \gamma^{2}}\left(1+\frac{K^{2}}{2}\right)
$$

(ただし， $\lambda_{\mathrm{FEL}}$ : XFELの波長， $\lambda_{\mathrm{u}}$ : アンジュレータ磁場 の周期長, $\gamma$ : 電子の相対エネルギー, $K$ : アンジュ レータの偏向パラメータを表す)の関係が成り立つこと から，XFEL装置の小型化は高エネルギー加速器の小型 
化，またはアンジュレータ磁場の短周期化(アンジュ レータ光の波長を一定とする場合, アンジュレータの磁 場周期を短くすると, 必要な電子エネルギーが小さくで きる)もしくは，その両方を実施することで原理的には 可能である ${ }^{3)}($ アンジュレー夕に関しては文献4)に譲 る)。ここで, $\mathrm{GeV}$ 級の高エネルギー加速器部の小型化 に期待されている方策がレーザー航跡場加速 (Laser Wakefield Acceleration: LWFA) である5). LWFAは高強度 超短パルスレーザーの伝搬に伴って励起される電子プラ ズマ波を利用した粒子加速法であり，この電子プラズマ 波が有する非常に大きな加速電場は高周波加速の1000倍 を越える $100 \mathrm{GV} / \mathrm{m} に も$ 達するため, 全長数百メートル の10 GeV級電子加速器部を数メートルの卓上サイズに まで小型化することができると期待される，自由電子 レーザー(Free Electron Laser: FEL)のドライバーとして レーザー航跡場加速を用いるアイディアはこれまでに提 案され既に開発競争が始まっている ${ }^{6-8)}$. 硬X線領域の FELで自己増幅放射 (Self-Amplified Spontaneous Emission: SASE)を行う為には, 電子ビームが $10 \mathrm{GeV}$ 級の加速工 ネルギーのみならず, 高い単色性 $(\Delta E / E<0.1 \%)$, 超低 エミッタンス性 $(<1 \pi \mathrm{mm} \cdot \mathrm{mrad}), \mathrm{kA}$ 級の大電流(極短 パルスかつ大電荷量)を同時に満足しアンジュレータへ 輸送されることも重要となる ${ }^{9)}$. 本稿では内閣府ImPACTプログラム「ユビキタス・パワーレーザーによる安 全・安心・長寿社会の実現」やの下で著者らが取り組ん でいる $\mathrm{GeV}$ 級ステージングレーザー航跡場加速研究の現 状をXFELのドライバー電子ビーム開発としての視点か ら概説した後, 理化学研究所播磨キャンパスにて構築を 進めているレーザー航跡場加速プラットホームの開発状 況を紹介する。

\section{2. ステージングレーザー航跡場加速}

レーザー航跡場加速は研究黎明期に目標とされた $\mathrm{GeV}$ 級の加速 ${ }^{10,11}$ や準単色ビーム発生 ${ }^{12-16)}$ の原理実証は 既に達成され, 電子加速機構としての高いポテンシャル が示されている。 しかしながら, 従来加速器のように電 子ビームを毎ショット再現性良く生成することが未解決 の大きな課題として残されている，高強度レーザーパル スを標的ガスに集光するだけの，所謂これまでのレー ザー航跡場加速においては, 非線形レーザー航跡場の中 でプラズマ波の破砕による電子入射(被加速電子の生成) とプラズマ波の超高電場による加速がほぼ同時に起こ る ${ }^{17,18)}$. フェムト秒スケールの極短・単色・高エネル ギーの電子バンチを毎ショット再現性良く生成するに は, $\sim 10$ ミクロン以下の微小領域に励起されるレー ザー航跡場の極めて狭い（１0フェムト秒以下の)加速 位相へ被加速電子を正確に入射する必要があり，これを 制御性の乏しい非線形航跡場の中で実施することは現在 の技術では不可能に近い. 加えて, 電子ビームの大電荷 量化に適切な標的のプラズマ密度と高エネルギー加速化
を目指す場合の標的密度はトレードオフの関係にあるた め, これらの両立は電子の入射と加速が同時に起こる従 来のレーザー航跡場加速では困難である.

これらを解決する方策として，ステージングレーザー 航跡場加速が提案されている ${ }^{19,20)}$. 複数の高強度レー ザーパルスでレーザー航跡場を駆動し，その機能を電子 入射と加速に分離(従来加速器の電子銃と加速管に相当) する. 2ステージ (二段)加速の例をFig. 1 に示す. ガス 標的の上流(高密度部)と下流(低密度部)にそれぞれ焦点 距離の異なる高強度レーザーパルス (レーザーパルス 1 , 2)を照射しそれらパルスの後方に機能の異なるレーザー 航跡場を励起する。 上流の非線形プラズマ波(レーザー 航跡場)の破砕が電子銃に相当しフェムト秒スケールの 極短電子バンチの発生を担い，加速管に相当する下流の 線形レーザー航跡場 (追加速場) がその電子バンチを追加 速する。このように, 機能の異なるレーザー航跡場をそ れぞれ独立に励起することで電子入射と追加速を同時に 最適化することができ，さらに相対的に制御性の高い線 形レーザー航跡場を追加速場とすることで電子入射の条 件を緩くすることができると期待される. Fig. 2 に追加 速場の標的密度に対する入射電子のエネルギーへの要求 值の簡単な見積もりを示す。文射電子のエネルギーは, 標的ガスのプラズマ密度に対するプラズマ波の群速度に 相対論効果を考慮し見積もられた ${ }^{21)}$ ，追加速には線形領 域近傍の $a_{0} \sim 1$ が用いられるが，これまでの非線形航跡 場 $a_{0} \sim 3,5$ の場合も比較として図中に示す。また, パル ス放電による長尺の追航跡場用の光導波路 (後述) 形成の 容易さを考慮して追加速の標的密度には $10^{18} \mathrm{~cm}^{-3}$ 近傍を 選択している。

ここで， $a_{0}$ は追加速レーザー航跡場を駆動するレー ザーの規格化強度であり(相対論的効果の目安となる 值), $a_{0}=e E_{0} /\left(m_{0} c \omega\right)=0.85 \lambda(\mu \mathrm{m}) I\left(10^{18} \mathrm{~W} / \mathrm{cm}^{2}\right)^{1 / 2}$ で表さ れる。ここで, $E_{0}$ はレーザー電場強度, $e$ は電子の電荷 量, $m_{0}$ は電子の静止質量, $\omega, \lambda$ はそれぞれレーザーの 角周波数と波長である。追加速はこの条件を満足するよ うに初段航跡場で電子(典型的には〜 $20 \mathrm{MeV}$ 以上) を生

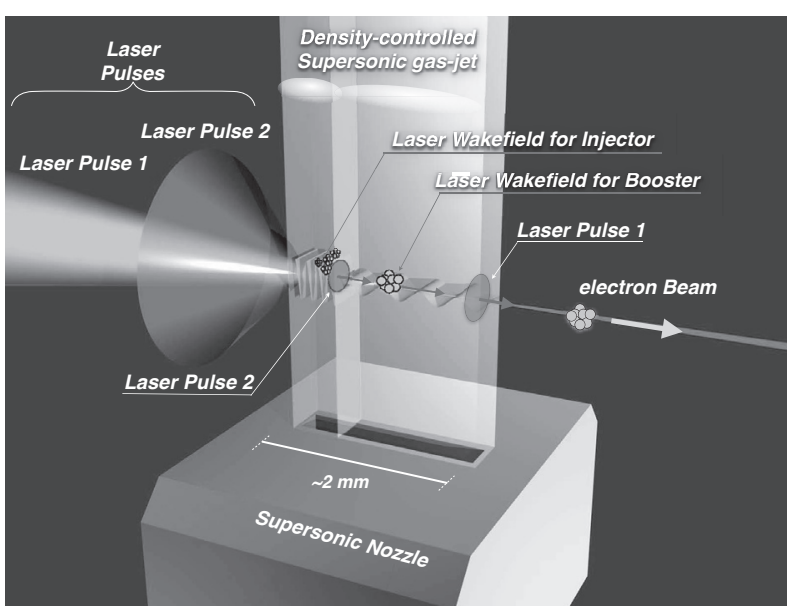

Fig. 1 Setup for 2-staged laser wakefield acceleration.

${ }^{\dagger 1}$ http://www.jst.go.jp/impact/sano/ 


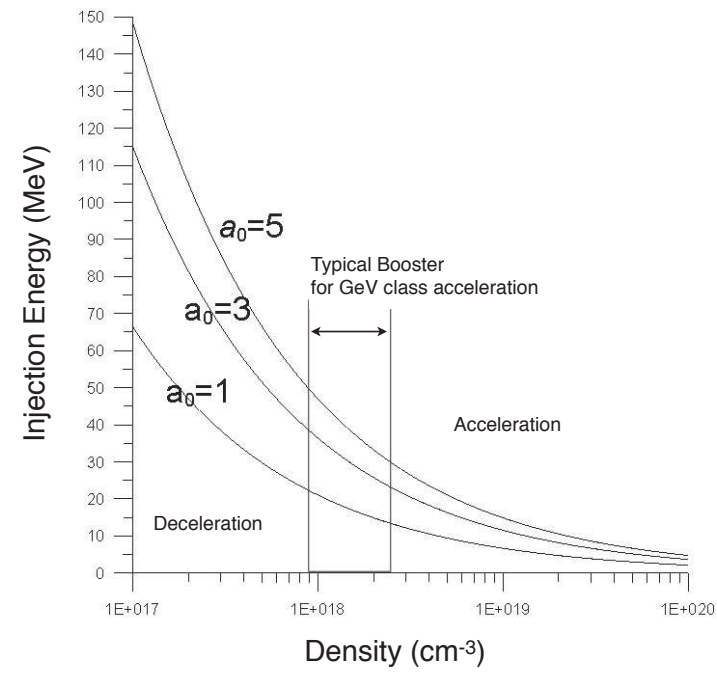

Fig. 2 Required injection energy of electron beam for staging acceleration.

成し追加速レーザー航跡場へ入射させる．電子をさらな る超高エネルギーへ加速するには追加速レーザー航跡場 のみを多段化すればよく，さらに電子入射のタイミング を調整することで追加速場での電子ビームのエネルギー スペクトルの狭帯化やパルス圧縮などの制御も可能にな $ろ^{22)}$.

\section{3. ステージング加速の開発状況}

\section{1. 電子入射用レーザー航跡場 (入射器)}

ステージングレーザー航跡場加速で制御性の高い電子 ビームを生成するには，各ステージで励起されるレー ザー航跡場の高い再現性が前提となる。しかし，レー ザー航跡場を励起する高強度レーザーパルスはガス標的 内部の初期密度擾乱によるレーザーパルスの回折, 高強 度レーザーパルスによる自己集束, イオン化による屈折 率分布の変化等の影響により安定な伝播を維持すること が難しく, そのようなレーザーパルスで励起される航跡 場には高い再現性を期待できない. その解決策として近 年, 著者らによりプラズママイクロオプティクス (Plasma Micro-Optics: PMO)が提案され, 高強度レーザー パルス伝播の安定化とともにレーザー航跡場から発生す る電子ビームの品質と安定性が飛躍的に向上した ${ }^{23,24)}$.

PMOとは光ファイバやレンズと同様のウエーブガイ ド機能や集光機能を持ち, テラワット級のハイパワー領 域のレーザー光にも使用可能なプラズマデバイスであ る 23,24$)$ PMOはガス標的内部のレーザー集光点付近に レーザー伝播軸方向に磁場を印加し，さらにレーザープ レパルスの強度・形などを適当に調整することにより形成 される。レーザー航跡場を励起するメインレーザーパルス が到着する前にこれを焦点付近に形成することにより高 強度のメインレーザーパルスの安定な伝播を可能とし指 向性の高い電子ビームの安定な発生に大きく寄与する。

Fig. 3 にステージング加速の際にシャドウグラフ法で 計測されたPMOのイメージを示す．レーザー集光点付

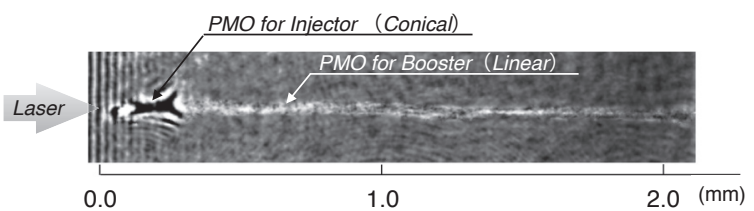

Fig. 3 Typical shadowgraph image of staging LWFA.

近に鼓形状のPMOとその後ろに長尺の直線状のPMOが 形成されている。この鼓形状のPMOがメインパルスに 対して集光オプティクスとして振る舞うことで，焦点付 近のレーザースポットサイズ程度の微小領域で強いプラ ズマ波破砕による電子入射が発生するようになり，極め て安定に指向性の良い大電荷量 $(>1 \mathrm{nC} / \mathrm{shot})$ かつ, 高工 ネルギーの電子ビーム $(<30 \mathrm{MeV})$ を発生する ${ }^{22}$.

Fig. 4 にPMOを採用した入射器からの電子ビームの空 間プロファイルとその電子ビームの位置安定性を示す.

また,このPMOによる光導波を用いて電子入射器から の電子ビームを正確にステアリング(射出方向の制御)す ることができることも最近示された25).

\section{2 追加速用レーザー航跡場 (ブースター)}

Fig. 5 にステージングレーザー航跡場加速の原理実証 の例として2段階のステージングレーザー航跡場加速で 得られた典型的なエネルギースペクトルを示す. Fig. 3 に示した追加速場となる長尺 $(\sim 2 \mathrm{~mm})$ 直線状のPMOは 光ファイバのように振る舞い, 入射電子ビームの高い指 向性と位置安定性 $( \pm 500 \mu \mathrm{rad}$ 以下 $)$ を維持したまま追加 速 $(\sim 100 \mathrm{MeV})$ と準単色化 $(\Delta E / E<10 \%)$ が同時に達成さ れた22)。この原理実証実験では，レーザー航跡場を励起
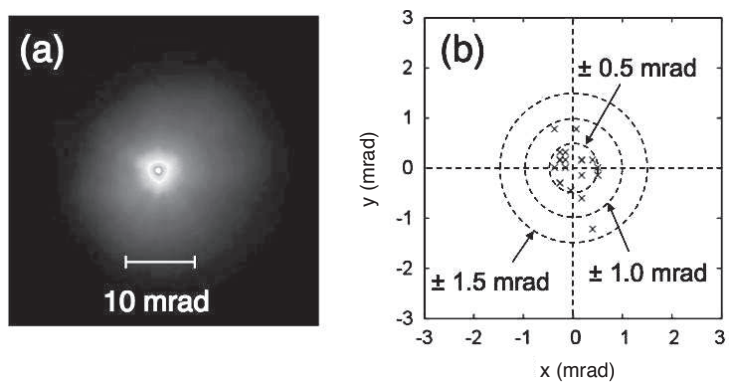

Fig. 4 Typical spatial profile (a) and pointing stability (b) of electron beams from injector.

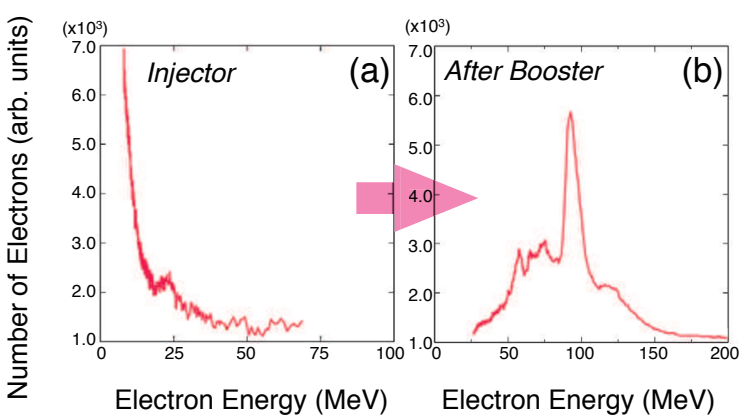

Fig. 5 Typical energy spectrum of electron beam of injector (a) and after booster (b). 
する主レーザーパルスのピコ秒前のプレパルス(ペデス タルパルス)をパルス圧縮器内回折格子の角度を調整す ることにより光ファイバ状のPMOを生成した。これに より，追加速場が形成される光ファイバ状PMOの有り 無しそれぞれの条件を作り出し, 入射電子の追加速を確 認している。最近は，脱位相長の長い $1 \times 10^{18} \mathrm{~cm}^{-3}$ 以下の 低密度領域での追加速場 (ブースター)の研究開発がビー 厶のGeV級高エネルギー化を念頭に進められており， $100 \mathrm{GV} / \mathrm{m}$ 以上の加速勾配と $1 \mathrm{GeV}$ に迫る加速エネルギー も観測され始めている。再現性の高い $\mathrm{GeV}$ 級高エネル ギー加速を目標に, より長尺の加速場 ( 10 cm級) 形成 のための高速パルス放電を用いた $\mathrm{PMO}^{26-29)}$ の開発も並行 して進められている。

PMOの登場によって電子ビームの位置安定性が従来 加速器並みに向上したことにより，従来加速器で使用さ れているビームオプティクスでのビームハンドリングも 可能になり既に使用が始まっている ${ }^{30)}$. 例えば集束用磁 気レンズとエネルギー選別スリットを用いて，10-100 $\mathrm{MeV}$ 級の電子ビームを $\Delta E / E \sim 1 \%$ 程度の単色性で再現性 良く切り出し(Fig. 6)下流に輸送することにも成功して いる. このように, 最近のレーザー航跡場加速はPMO と従来ビームオプティクスの組み合わせにより電子ビー ムの制御性が格段に向上している.

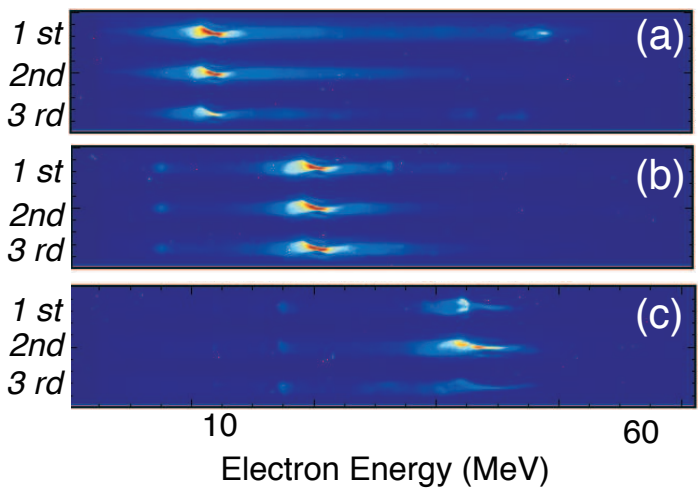

Fig. 6 Typical images of screen on electron energy spectrometer that indicate energy spectra of energy-sliced electron beams of injector. The vertical axis indicate 3 successive shots for 3 different slicing conditions of (a)-(c).
4. レーザー航跡場加速プラットホーム

4.1. プラットホームの概念設計

内閣府ImPACTプロジェクト「ユビキタス・パワー レーザーによる安全・安心・長寿社会の実現」では, レーザー航跡場加速駆動のX線自由電子レーザーの実現 を究極の目標に設定し，レーザー航跡場電子加速に関す る要素技術開発が進められている7)。プログラムでは大 阪大学, 量子科学技術研究開発機構 (QST) 関西研究所, 長岡科学技術大学等の参画機関で開発されている要素技 術を理化学研究所播磨SPring-8キャンパスに構築される レーザー航跡場加速プラットホームにて統合し, 加速長 $10 \mathrm{~cm}$ 以下で $1 \mathrm{GeV}$ 以上，エネルギー広がり $1 \%$ 以下，パ ルス幅〜 $10 \mathrm{fs}$, エミッタンス< $1 \mathrm{~mm} \cdot \operatorname{mrad}$ 以下のビーム を再現性よく発生するレーザー航跡場駆動の $\mathrm{GeV}$ 級実用 電子加速技術の確立を目指す。さらに, このレーザー駆 動電子加速器を高エネルギー加速器研究機構 (KEK) で 開発中のマイクロアンジュレーター ${ }^{4)}$ と組み合わせ, $\mathrm{X}$ 線自由電子レーザーを含む軟X線〜X線領域の極短波長 放射光源の研究開発が推進される。このレーザー航跡場 加速プラットホームはSCSS (SPring-8 Compact SASE Source) 計画 ${ }^{22} て ゙$ 使用されていた加速器トンネルを用いて 展開することがImPACTプログラムで承認され，既にト ンネル内にはプラットホームレーザーの為のクリーン ルーム建設が進められている。Fig.7 にレーザー航跡場 加速プラットホームの概念図を示す。再現性の高い安定 な $\mathrm{GeV}$ 級の加速を実現する為に前章で述べたステージン グレーザー航跡場加速を採用し，初段は電子入射，二段 目は位相回転(単色化)と追加速，三段目は追加速の機能 をそれぞれのレーザー航跡場が担う。それぞれのレー ザー航跡場を励起する三つのレーザーパルスは正確に時 間同期し，さらにそれぞれの航跡場の機能に最適化され たエネルギーとパルス幅に調整される。なお追加速部を モジュール化し段数を加えていくことでより高い加速エ ネルギーを目指すことも検討されている。

\section{2. プラットホームレーザー}

構築している多段レーザー航跡場加速用レーザーシス テムの構成図をFig. 8 に示す．フロントエンドシステム にはチャープパルス増幅方式の40 TW級のチタンサファ イアレーザーを用いる。 三つのレーザー航跡場の正確な

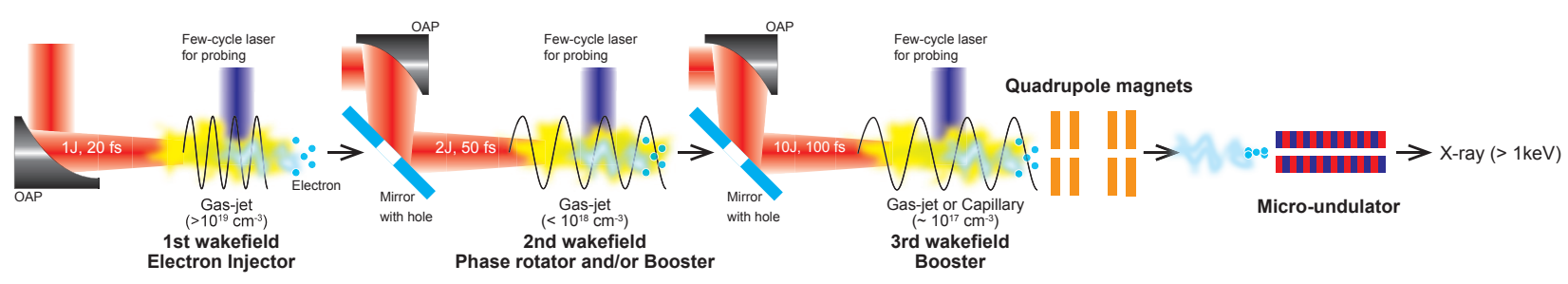

Fig. 7 Conceptual design of LWFA platform at ImPACT program.

\footnotetext{
${ }^{\dagger 2}$ http://xfel.riken.jp/sacla/index00.htm
} 


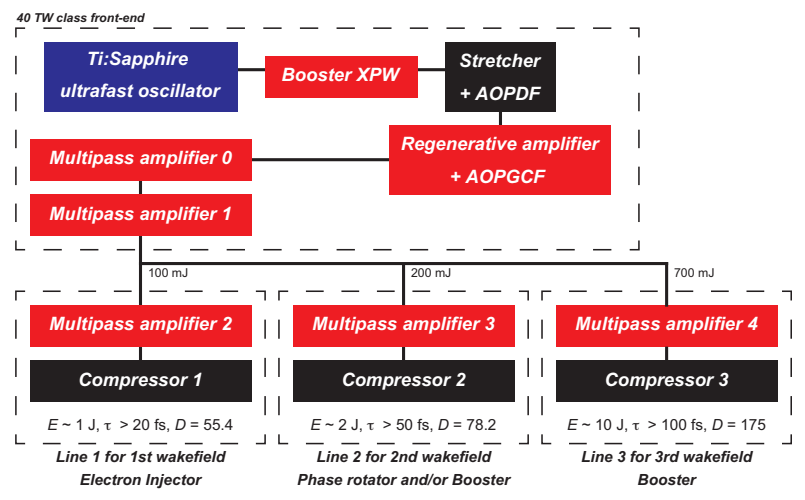

Fig. 8 Schematic diagram of laser system for LWFA platform.

時間同期を得るためにフロントエンドシステムから射出さ れるレーザーパルスを三つのレーザーパルスに分岐した 後にそれぞれ独立の増幅器を用いて1 パルス当たり $1.5 \mathrm{~J}$, $3 \mathrm{~J}, 14 \mathrm{~J}$ Jで増幅する。 さらにそれぞれのレーザーパル スを各段のレーザー航跡場に最適なパルス幅とチャープ とする為にそれぞれ独立にパルス圧縮を行う. 最終的に プラットホームレーザーシステムから射出される三つの レーザーパルスは電子入射, 位相回転器, 追加速の機能 に特化したプラズマ波を励起するため, それぞれ1パル ス当たり $1 \mathrm{~J}-20 \mathrm{fs}, 2 \mathrm{~J}-50 \mathrm{fs}$ 及び $10 \mathrm{~J}-100 \mathrm{fs}$ に調整され る.パルスの繰返しはそれぞれ初段 $10 \mathrm{~Hz}$ ，二段 $5 \mathrm{~Hz}$, 三段 $0.1 \mathrm{~Hz}$ である.

理化学研究所播磨キャンパスの旧SCSSトンネルに構 築中のプラットホームレーザーシステムの鳥瞰図を Fig. 9 に示す。トンネルの一部を精密に温度湿度管理し たクリーンルームに改造し全てのレーザーコンポーネン トを一列に配置しトンネンル内部に収納する。ただし振 動の大きな真空ポンプ類, 排熱の大きな各種電源類, 最 終段アンプ用のポンプレーザーはトンネル外に設置す る. ステージングレーザー航跡場加速では複数のレー ザー航跡場の空間的な重ね合わせが安定かつ再現性の良 い電子ビーム発生にとって極めて重要であることがこれ までの研究開発により明らかにされており, このレー ザー航跡場同士の軸ずれを防ぐ為に三つの（初段，二段 及び三段の航跡場を励起する) レーザーパルスを伝送す る全ての光学コンポーネントを一枚の光学テーブル上に 配置する構成を採用している。同様の理由から三つのパ ルス圧縮器ユニットも真空容器中に設置した一枚の光学 定盤上に並列に配置される。さらにトンネル内部の床は 強固な一枚の岩盤で構成されており，レーザーシステ ム, パルス圧縮器用真空容器及びレーザー航跡場加速 ビームライン等全ての機器をトンネル内部に設置するこ とで外部からの振動を高いレベルで避けることができ る。レーザー装置は平成 28 年度末の設置完了, プラット ホーム構築は平成29年度上半期の完了を目指しており, その後ImPACTプロジェクト終了までに $1 \mathrm{GeV}$ 級電子の 安定発生とマイクロアンジュレーターを用いた $\mathrm{keV}$ 領域

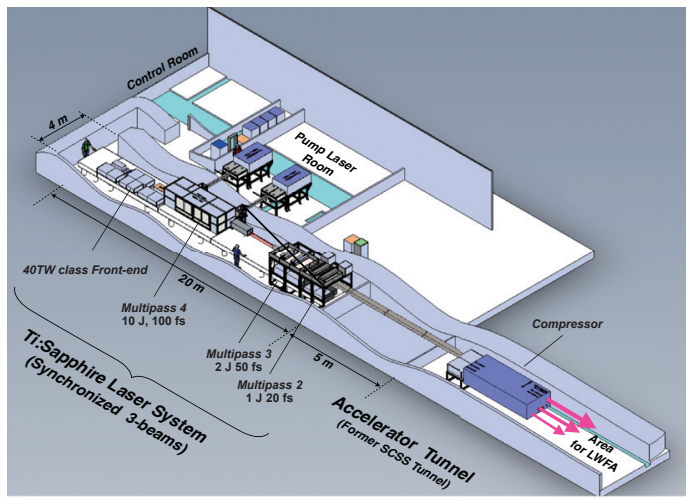

Fig. 9 Bird's-eye view of laser system for LWFA platform in former SCSS accelerator tunnel.

までのX線放射の観測及びX線自由電子レーザー実現へ の指針を得る計画である。

\section{5. まとめと今後の展望}

本稿では内閣府革新的研究開発推進プログラムIm$\mathrm{PACT}\lceil$ ユビキタス・パワーレーザーによる安全・安心・ 長寿社会の実現」のもとで実施されているレーザー航跡 場加速電子ビーム駆動XFELの実現を究極目標に設定し たレーザー航跡場加速要素技術開発とレーザー航跡場加 速統合プラットホーム開発について概説した。レーザー 航跡場加速研究は $\mathrm{GeV}$ 級の加速や準単色電子の発生など 原理実証が既に為され，現在は加速器実現に向かう過渡 期にある。これまでのようなレーザー入力を大強度化す るだけの力任せの加速では, 到達加速エネルギーのチャ ンピオンレコードは更新されても，それらによってレー ザー航跡場加速が現実の加速器に近づくことはない．一 方PMOの登場によって電子ビームの位置安定性が従来 加速器並みに向上し, 従来加速器で使用されているビー ムオプティクスを用いたビームハンドリングが可能にな り電子ビームの制御性が劇的に向上した。このような状 況を背景にレーザー航跡場加速ベースのXFEL開発への チャレンジがImPACTプログラムに採択された。これま でにプログラムではエネルギー選別によるエネルギー広 がり $\Delta E / E<1 \%$ の $100 \mathrm{MeV}$ 級電子ビームの安定生成や追 加速パラメータでの $\mathrm{GeV}$ 級電子ビーム加速などが達成さ れた。これらの成果をもとに再現性の高い $\mathrm{GeV}$ 級の高工 ネルギー加速へと研究開発は展開し， ～10 cm級の長尺 $\mathrm{PMO}$ の開発も現在進んでおり，その実現も近い。今後 高エネルギー電子ビーム発生の安定化が進むに従い, 従 来加速器技術によるビームの輸送と制御の技術がより一 層重要になる。これからのレーザー航跡場加速器実現を 含めたレーザー航跡場加速の展開は，プラズマダイナミ クスを含めた粒子加速機構の詳細にわたる理解をべース とした研究開発とともに, 最先端の加速器技術との融合 が不可欠になる。近年，米国や欧州では粒子加速を含む ハイパワーレーザー応用に携わる研究者と大型加速器施

\footnotetext{
${ }^{\dagger 3}$ http://www.eupraxia-project.eu/
} 
設の研究者が連携協力しレーザー駆動の超小型高エネル ギー粒子加速器の実現に向けた研究体制を確立しつつあ る ${ }^{\dagger 3}$. 日本がこの研究分野のトップランナーであり続け るためには，ImPACTプログラムで開始されたレーザー 航跡場加速電子によるXFEL開発をさらに大きく展開し, オールジャパンの研究体制の構築が急務である。その為 にも現在著者らが構築中のレーザー航跡場加速プラット ホームを多くの方々に有効に利用して頂き，それにより レーザー航跡場加速器研究が大きく拓かれていくことを 期待したい.

\section{謝 辞}

本研究は, 内閣府革新的研究開発推進プログラム Im$\mathrm{PACT}\lceil$ ユビキタス・パワーレーザーによる安全・安心・ 長寿社会の実現」の支援を戴き実施しております。暖か いご支援とご指導を戴いておりますプロジェクトマネー ジャーの佐野 雄二博士に篤く御礼申し上げます。また, 本稿をまとめるに当たりご助言頂きました理化学研究所 矢橋 牧名博士に感謝申し上げます。

\section{参考文献}

1）矢橋牧名, 富樫 格, 永園 充, 田中均, 石川哲也: レー ザー研究 37 (2009) 879.

2) 矢橋牧名：レーザー研究 40 (2012) 675

3) 石川哲也：光学 $\mathbf{4 3}$ (2014) 406

4) 山本樹：レーザー研究 45 (2017) 82

5) T. Tajima and J. M. Dawson: Phys. Rev. Lett. 43 (1979) 267.

6) M.-E. Couprie: レーザー研究 45 (2017) 94.

7) A. R. Maier, A. Meseck, S. Reiche, C. B. Schroeder, T. Seggebrock, and F. Grüner: Phys. Rev. X 2 (2012) 031019.

8) C. B. Schroeder, W. M. Fawley, F. Gruner, M. Bakeman, K. Nakamura, K. E. Robinson, Cs. Toth, E. Esarey, and W. P. Leemans: AIP Conf. Proc. 1086 (2009) 637.

9）田中均: “X線自由電子レーザー概論”, 高エネルギー加速 器セミナー(OHOテキスト, 2013).

10) W. P. Leemans, B. Nagler, A. J. Gonsalves, Cs. Tóth, K. Nakamura, C. G. R. Geddes, E. Esarey, C. B. Schroeder, and S. M. Hooker: Nat. Phys. 2 (2006) 696.

11) S. Karsch, J. Osterhoff, A. Popp, T. P. Rowlands-Rees, Zs Major, M. Fuchs, B. Marx, R. Hörlein, K. Schmid, L. Veisz, et al.: New J. Phys. 9 (2007) 415.
12) S. P. D. M angles, C. D. M urphy, Z. Najmudin, A. G. R. Thomas, J. L. Collier, A. E. Dangor, E. J. Divall, P. S. Foster, J. G. Gallacher, C. J. Hooker, et al.: Nature 431 (2004) 535.

13) C. G. R. Geddes, Cs. Toth, J. van Tilborg, E. Esarey, C. B. Schroeder, D. Bruhwiler, C. Nieter, J. Cary, and W. P. Leemans: Nature 431 (2004) 538.

14) J. Faure, Y. Glinec, A. Pukhov, S. Kiselev, S. Gordienko, E. Lefebvre, J.-P. Rousseau, F. Burgyand, and V. Malka: Nature 431 (2004) 541

15) E. Miura, K. Koyama, S. Kato, N. Saito, M. Adachi, Y. Kawada, T. Nakamura, and M. Tanimoto: Appl. Phys. Lett. 86 (2005) 251501.

16) A. Yamazaki, H. Kotaki, I. Daito, M. Kando, S. V. Bulanov, T. Zh. Esirkepov, S. Kondo, S. Kanazawa, T. Homma, K. Nakajima, et al.: Phys. Plasmas 12 (2005) 093101.

17) N. A. M. Hafz, T. M. Jeong, I. W. Choi, S. K. Lee, K. H. Pae, V. V. Kulagin, J. H. Sung, T. J. Yu, K Hong, T. Hosokai, J. R. Cary, et al.: Nat. Photonics 2 (2008) 571.

18) A. Pukhov and J. Meyer-Ter-Vehen: Appl. Phys. B 74 (2002) 355.

19) A. J. Gonsalves, K. Nakamura, C. Lin, D. Panasenko, S. Shiraishi, T. Sokollik, C. Benedetti, C. B. Schroeder, C. G. R. Geddes, J. van Tilborg, et al.: Nat. Phys. 7 (2011) 862.

20) S. Steinke, J. van Tilborg, C. Benedetti, C. G. R. Geddes, C. B. Schroeder, J. Daniels, K. K. Swanson, A. J. Gonsalves, K. Nakamura, N. H. Matlis, et al.: Nature 530 (2016) 190.

21) E. Esarey, P. Sprangle, J. Krall, and A. Ting: IEEE Trans. Plasma Sci. 24 (1996) 252.

22) T. Hosokai, A. Zhidkov, A. Yamazaki, Y. Mizuta, M. Uesaka, and R. Kodama: Appl. Phys. Lett. 96 (2010) 121501.

23) Y. Mizuta, T. Hosokai, S. Masuda, A. Zhidkov, K. Makito, N. Nakanii, S. Kajino, A. Nishida, M. Kando, M. Mori, et al.: Phys. Rev. ST Accel. Beams 15 (2012) 121301

24) T. Hosokai, K. Kinoshita, A. Zhidkov, A. Maekawa, A. Yamazaki, and M. Uesaka: Phys. Rev. Lett. 97 (2006) 075004.

25) N. Nakanii, T. Hosokai, K. Iwasa, S. Masuda, A. Zhidkov, N. Pathak, H. Nakahara, Y. Mizuta, N. Takeguchi, and R. Kodama: Phys. Rev. ST Accel. Beams. 18 (2015) 021303.

26) Y. Ehrlich, C. Cohen, A. Zigler, J. Krall, P. Sprangle, and E. Esarey: Phys. Rev. Lett. 77 (1996) 4186.

27) T. Hosokai, M. Kando, H. Dewa, H. Kotaki, S. Kondo, N. Hasegawa, K. Nakajima, and K. Horioka: Opt. Lett. 25 (2000) 10.

28) A. Butler, D. J. Spence, and S. M. Hooker: Phys. Rev. Lett. 89 (2002) 185003

29) T. Kameshima, H. Kotaki, M. Kando, I. Daito, K. Kawase, Y. Fukuda, L. M. Chan, T. Homma, S. Kondo, T. Z. Esirkepov, et al.: Phys. Plasmas 16 (2009) 093101.

30) N. Nakanii, T. Hosokai, S. Masuda, A. G. Zhidkov, Z. Jin, Y. Mizuta, H. Nakahara, S. Kajino, K. Makito, A. Nishida, et al.: Proc. International Conference on High Energy Density Sciences 2012 (2012) HED-P12. 